\title{
THE IMPORTANCE OF SALT EXPLOITATION IN ROMAN DACIA. THE CASE OF OCNA MUREȘ (SALINAE)
}

\begin{abstract}
The current paper presents a part of the epigraphic file of Ocna Mureș (the ancient Salinae), taking into account the brick stamps containing the name of the legio XIII Gemina and the names of magistri figlinae. Putting together the epigraphic evidences, the author shows the importance of the salt exploitation at Ocna Mureș for the Roman army.
\end{abstract}

Keywords: Roman Dacia, Salinae, salt exploitation, Roman army

$\mathbf{R}$ ather recently I published a study on the personnel of the saltmines from Roman Dacia, in which I showed that the salt functionaries under lessees (conductores) were extremely engaged in this economic sector, directly operating on the field. ${ }^{1}$

The exploitation of salt in this province has enjoyed attention particularly in the wider context of analysing how its underground riches were exploited. V. Wollman compiled the list of the main salt exploitation centres of Dacia: Ocna Mureș, Potaissa, Ocna Sibiului, Cojocna Sic, Pata, Ocna Dejului, Domnești, Ocnele Mari. ${ }^{2}$ In a study concerning the administration of the Dacian saltworks, D. Benea noted that the locations of salt exploitation are linked to the presence of the Roman army in the area, meant to safeguard the resources. ${ }^{3}$ She exemplifies with the castra from Sânpaul (for the halite deposits from Mărtiniș), Sărățeni (for Sovata), Inlăceni (for Praid), Ilișua (for Domnești), Gherla (for Ocna Dejului), and Potaissa (for Turda). ${ }^{4}$ These military camps have been documented both archaeologically and epigraphically. ${ }^{5}$

Now, what can be said about Ocna Mureș? Identified with the ancient settlement Salinae, the archaeological excavations in this site have revealed the traces of a castrum. V. Wollmann states that the remains of a Roman surface exploitation and of buildings used for this purpose between Ocna Mureș and Șpălnaca were still visible in the $19^{\text {th }}$ century. ${ }^{6}$ On the other bank of the Mureș is the camp from Războieni-Cetate, which garrisoned the ala I Batavorum, documented and investigated archaeologically. ${ }^{7}$ In any case, Ocna Mureș is located at ca. $55 \mathrm{~km}$ to the north-west of Alba Iulia, the headquarters

\footnotetext{
MIHAILESCU-BÎRLIBA 2016, 51-58.

WOLLMANN 1996, 240-244.

BENEA 2007, 42-43.

BENEA 2007, 42.

See more recently MATEI-POPESCU/ȚENTEA 2016, 10-11 (Săă̆țeni, Inlăceni), 13 (Sânpaul).

WOLLMANN 1996, 241. see also OLTEAN 2007, 182.

Selective bibliography: POPOVICI/VARGA 2010; VARGA 2012, 806-820; BOUNEGRU/ VARGA 2017, 47-51.
}

\section{Lucrețiu Mihailescu-Bîrliba} „Alexandru Ioan Cuza” University of Iași blucretiu@yahoo.com

DOI: $10.14795 /$ j.v5i4.347

ISSN 2360 - 266X

ISSN-L 2360 - 266X 
of the legio XIII Gemina (see map).

Foremost represented by the stamped bricks of the aforementioned legion, the epigraphic assemblage from Ocna Mureș also contains other interesting inscriptions, which we will discuss below. The bricks bearing the stamp of the legion are accompanied by anthroponyms of cives Romani, which are probably magistri figlinae (or figlinarum) - soldiers tasked with overseeing the manufacturing workshops. This is indicated by a stamp from Apulum in which the name of Aurelius Godes (also mentioned at Ocna Mureș) is accompanied by the group of letters ' $\mathrm{M} \mathrm{F}$ ' (interpreted by C. Băluță as manu fecit, but actually designating responsibility - magister figlinae or figlinarum $)^{8}$ B. Lörincz helds that these magistri figlinarum were regular soldiers, perhaps immunes ${ }^{9}$, a view also shared by Y. le Bohec. The few stone inscriptions with direct or indirect references-from Germania Inferior (Iulius Victor - magister figlinarum, ${ }^{10}$ two immunes figlinarum ${ }^{11}$ ), Germania Superior (one custos castelli figlinarum $^{12}$, and Dacia (Drobeta - one in figlinis magister super milites $L X$ ) - confirm that these magistri were soldiers of the legion tasked with superintending the production of bricks on the property (properties) in which the legion's workshops were found.

Besides Aurelius Godes, to whom this responsibility can be assigned, the other individuals lack such functions assigned to their names, but it follows that they were likewise soldiers of the legion (being Roman citizens) with similar attributions.

It must be stated from the onset that the presence of these stamped bricks at Ocna Mureș does not necessarily imply the presence of the legion in that place. But considering the number of such materials, the proximity to Apulum, and the economic and strategic importance of the exploitation from Salinae, the discussion is more complex and will be detailed after enumerating the more important epigraphic mentions from this settlement.

Thus, Ocna Mures, yielded two bricks of the legio XIII Gemina bearing the name of Lucretius Aquila ${ }^{13}$. Besides Apulum, ${ }^{14}$ tiles bearing the name of the same soldier are furthermore found at Germisara, ${ }^{15}$ Micia, ${ }^{16}$ Sebes, ${ }^{17}$ Sighișoara, ${ }^{18}$ Ulpia Traiana Sarmizegetusa ${ }^{19}$, and Ampelum. ${ }^{20} \mathrm{C}$. Băluță places these tegulae, on the basis of an archaeological context (presented superficially), not earlier than the rule of Marcus Aurelius ${ }^{21}$, but it's not excluded that they date from much later, starting with Caracalla ${ }^{22}$.

Flavius Heliodorus is another name mentioned on

\footnotetext{
8 IDR III/6, 163. see BENEA 2005, 143-150; BENEA 2010, 207.

LÖRINCZ 1991, 192-194; LE BOHEC 1992, 51-52.

CIL XIII 8739.

AE 1930, 33

KURZMANN 2005, 412

IDR III/6, 225, 228.

${ }_{14}$ AE 1965, 39-14; 1995, 1293s; IDR III/6, 226-227, 229; OTA/LASCU 2011, 208-209 etc.

15 IDR III/3, 226-4B.

16 IDR III/3, 195-18A-B.

17 AE 1971, 375F.

18 CIL III 8065-31I.

${ }^{19}$ IDR III/2, 541-7.

20 AE 1911,37

${ }^{21}$ IDR III/6, 226 sqq., sub numero.

22 OTA, LASCU 2011, 209
}

the stamped tegulae from Ocna Mureș. ${ }^{23}$ The same name is found on bricks of the legio XIII Gemina from Ulpia Traiana Sarmizegetusa, ${ }^{24}$ Micia $^{25}$ and, surely, Apulum. ${ }^{26}$ The archaeological contexts in which the stamps were found are not relevant, so we can date these bricks to the last quarter of the $2^{\text {nd }}$ century and the first half of the $3^{\text {rd }}$ century.

Iulius Deiotarus ${ }^{27}$ and Ulpius Fronto ${ }^{28}$ are two names of magistri figlinarum attested at Ocna Mureș. Both names are recorded elsewhere in Dacia. Besides Apulum ${ }^{29}$, Iulius Deiotarus is also attested at Micia. ${ }^{30}$ Ulpius Fronto is attested only at Apulum. ${ }^{31}$ Like in the previous cases, the tegulae date not earlier than the last quarter of the $2^{\text {nd }}$ century.

Another soldier mentioned on the stamped bricks from Ocna Mureș is Aurelius Dionisius ${ }^{32}$, a name also found at Apulum. ${ }^{33}$ An Aurelius Dionisius consacrates an altar at Micia to the Genius Turmazgadas ${ }^{34}$, a Syrian god ${ }^{35}$. With the cohors II Flavia Commagenorum having stationed at Micia, we can presume that the Aurelius Dionisius from here was a curator in this military unit. This makes it hard to identify this curator cohortis with the soldier from the stamps of Apulum. In any case, the gentilicium Aurelius argues for a dating of these stamps starting with Caracalla.

Another name encountered on the bricks from Salinae is that of Aurelius Callistratus. ${ }^{36}$ Besides Apulum, ${ }^{37}$ tiles mentioning his name have also been found at Micia and its environs ${ }^{38}$. His onomastics point to a dating starting with the rule of Caracalla.

I also propose the same dating for the stamps bearing the name of soldier Aurelius Caius ${ }^{39}$ attested, besides Apulum $^{40}$, at Ulpia Traiana Sarmizegetusa ${ }^{41}$ and also Sighișoara. ${ }^{42}$

A frequent name encountered on the tegulae is that of Aurelius Enthimus. At Ocna Mureș it is found once ${ }^{43}$. Besides Apulum and its environs ${ }^{44}$, his name is also attested

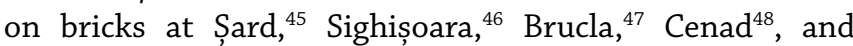
Sânnicolau Mare. ${ }^{49}$ Al. Flutur proposed in the case of the discoveries from Cenad and Sânnicolau Mare that the bricks

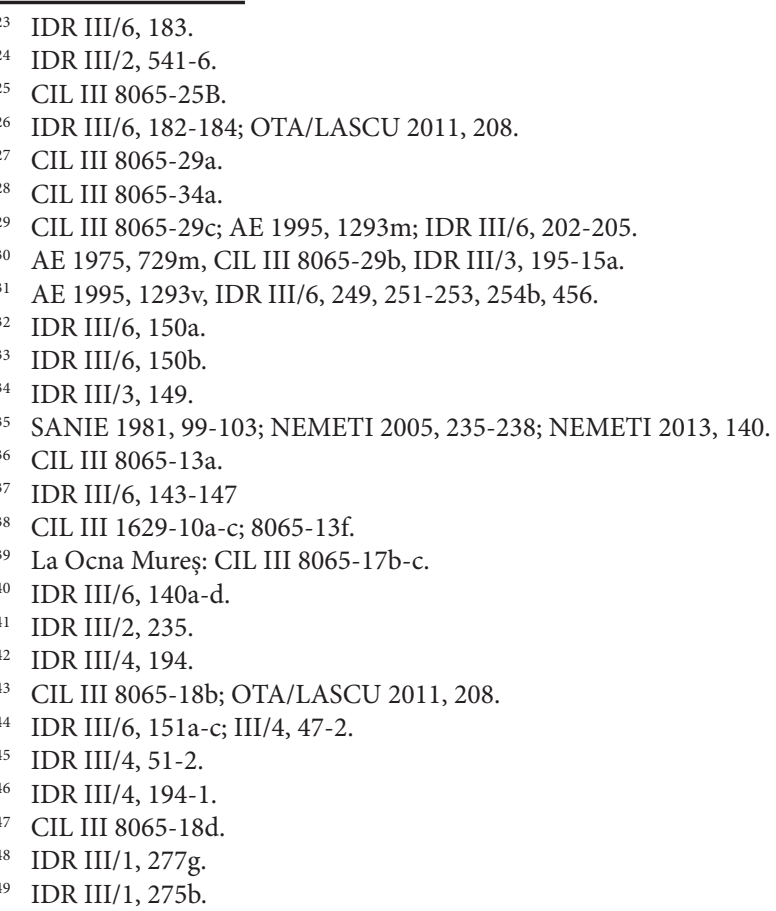


were carried there sometimes in the Middle Ages. ${ }^{50}$ This is possible, but a Roman military presence should not be excluded. That no Roman fortifications have been found does not necessarily prove that soldiers of the legio XIII Gemina were not stationed there. In this case too, I incline towards a dating post-Caracalla.

Aurelius Menander is attested on the stamps of two bricks from Salinae ${ }^{51}$. Besides Apulum and its environs ${ }^{52}$, this name is attested at Ulpia Traiana Sarmizegetusa, ${ }^{53}$ Sebes, ${ }^{54}$ Potaissa $^{55}$ and Micia ${ }^{56}$. I'm inclined to assign these bricks likewise to the $3^{\text {rd }}$ century, in any case after 212.

Also from the same period date the stamped bricks bearing the name of Aurelius Mommo, numbering two at Ocna Mureș ${ }^{57}$. The name of this magister figlinae is found, besides Apulum, ${ }^{58}$ at Ulpia Traiana Sarmizegetusa ${ }^{59}$ and Micia. ${ }^{60}$

Finally, Aurelius Godes, magister figlinae of legio XIII Gemina, is found in two instances at Salinae. ${ }^{61}$ His name is obviously attested at Apulum and the surrounding area, ${ }^{62}$ but also at Ulpia Traiana Sarmizegetusa, ${ }^{63}$ Păuca, ${ }^{64}$ Cenad $^{65}$, and Sânnicolau Mare. ${ }^{66}$ Like in the case of the other Aurelii magistri figlinarum, these bricks date from the period after 212.

The epigraphic assemblage from Ocna Mureș contains several other interesting texts. One is a votive inscription to Apollo by Atilius Celsianus, decurio. ${ }^{67}$ The character is undoubtedly decurio in an auxiliary unit, very likely the ala I Batavorum, located nearby, at Războieni-Cetate (Ad Vatabos).

An extremely fragmentary funerary text mentions another decurio, most likely belonging to the same unit ${ }^{68}$ : Aurelius C[api?]to, tesserarius in legio $V$ Macedonica is commemorated by his wife Aelia Candida. On account of the name of the character and the date of the legion's presence in Dacia, the inscription can definitely be dated after Caracalla, but it also shows that the soldiers of this legion had brief missions at Salinae.

Finally, we cannot conclude the review of the most important inscriptions from this settlement without mentioning the altar dedicated to the goddesses Diana and Terra Mater by a character (or characters) whose name(s) has not been preserved. ${ }^{69}$ Terra Mater is a divinity worshiped in the mining areas of the Balkan-Danubian provinces. ${ }^{70}$ In Moesia Superior, in the Rudnik mining area, the temple of the goddess, ruined by old age, is rebuilt under the rule

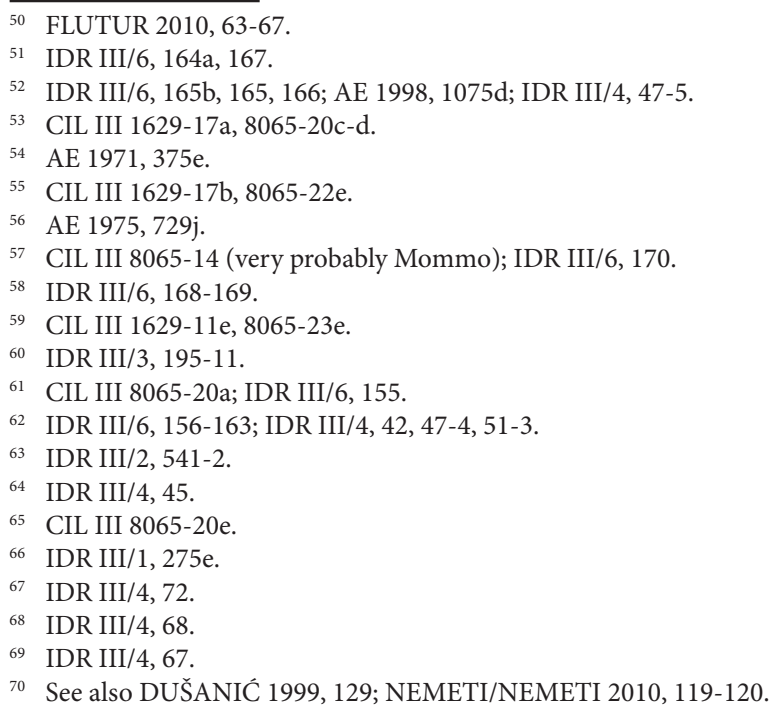

of Septimius Severus. ${ }^{71}$ In Dalmatia, in the Ljubija mining district, Terra Mater is found on six dedications, on part of functionaries from the iron exploitation administration. ${ }^{72}$ In Dacia, three inscriptions come from the Alburnus Maior area, the main centre of gold mining. They were produced by the workers of the gold mines. ${ }^{73}$ Besides the inscription from Salinae, Terra Mater is also mentioned in two centres of salt exploitation, specifically at Potaissa (Roman citizens from the vicus through the intercession of magistri) ${ }^{74}$ and Domnești (by Atticus, actor of Publius Aelius Marius, conductor pascui et salinarum) ${ }^{75}$ The text from Salinae, albeit fragmentary, is linked to the exploitation of salt in this place.

The epigraphic dossier from Ocna Mureș, even if it has not been presented exhaustively, is particularly relevant for underlying the importance of salt exploitation in the area. The ancient name of the settlement, corroborated by the altar dedicated to the goddess Terra Mater, discussed above, confirm the exploitation of this resource in the present-day Ocna Mureș. The stamped bricks likewise have special significance. It could be argued that their presence does not necessarily imply the presence of legionnaires. But we notice that at Salinae the most frequent mentions are of magistri figlinarum of legio XIII Gemina, whose activity span most probably from the end of the $2^{\text {nd }}$ century to the middle of the $3^{\text {rd }}$ century. The stamped bricks bear the name of no less than eleven magistri figlinarum: Lucretius Aquila, Flavius Heliodorus, Iulius Deiotarus, Ulpius Fronto, Aurelius Dionisius, Aurelius Callistratus, Aurelius Caius, Aurelius Enthimus, Aurelius Menander, Aurelius Mommo, Aurelius Godes. Many of these (foremost the Aurelii) bear Greek (Heliodorus, Dionisius, Callistratus, Enthimus, Menander) or Eastern (Godes) cognomina. The proximity to Apulum and the importance of the resource for the army, as well as for the civilian populace, explains the large number of individuals mentioned on the stamped bricks. Even if a castrum of a military unit has not been discovered, the presence of soldiers in mission cannot be denied. In point of fact, the inscription Atilius Celsianus or the epitaph of Aurelius C[api?] to clearly shows that the soldiers of the alae I Batavorum and of the legio V Macedonica were present at Salinae. Even though the castrum from Războieni-Cetate was closer to Salinae than Apulum, the number of soldiers from the legion and the power of the legion account for the control of this territory by the legio XIII Gemina. In point of fact, a stamped brick with the name of the legion was even found in the camp from Războieni-Cetate ${ }^{76}$.

To conclude, several soldiers were present at Salinae, most from legio XIII Gemina, tasked with ensuring the protection of the salt exploitation in the region. Very probably, their number varied throughout time and according to the efficiency of exploitation, though a higher concentration of troops occurred at the end of the $2^{\text {nd }}$ century and probably

\footnotetext{
ILJug 71. See also HORSTER 2001, 411.

IlJug 158-159, 161, 778-781. S. also MIHAILESCU-BÎRLIBA 2006, 153 $154,162-163$.

73 ILD 378, 397, 409.

4 ILD 500.

5 ILD 804. I have adopted the lecture of DANA/ZĂGREANU 2013, 31, more plausible than that of BENEA 2007, 43 (see also MIHAILESCU-BÎRLIBA 2016, 54, 57)

IDR III $/ 4,77$
} 
under the Severans.

\section{ACKNOWLEDGEMENT.}

This work was supported by a grant of Ministry of Research and Innovation, CNCS-UEFISCDI project PNIII-P4-ID-PCE-2016-0759, no 151/2017, EthnosalRo3 The Ethnoarchaeology of Salt in the Inner Carpathian area of Romania.

\section{REFERENCES}

$\mathrm{AE}$

BENEA 2005

L’Année Épigraphique (Paris).

Benea, D., Aurelius Godes magister figlinarum legionis XIII Geminae, Banatica 17, 143-149.

BENEA 2007

Benea, D., Cu privire administrarea salinelor din Dacia romană, Analele Banatului S. N. 15, 41-46.

BENEA 2010

Benea, D., Condiderații privind organizarea cărămidăriei legiunii a XIII-A Gemina de la Apulum, Bibliotheca Historica et Archaeologica Universitatis Timisiensis 12, 201-213.

BOUNEGRU/VARGA 2017

Bounegru, G./Varga, R., Toy fragments discovered in northern vicus of Războieni-Cetate (Alba County), Journal of Ancient History and Archaeology 4/1, 47-51. http://jaha. org.ro/index.php/JAHA/article/view/230/183 (DOI: 10.14795/j.v4i1.230).

CIL

Corpus Inscriptionum Latinarum (Berlin).

DANA/ZAGREANU 2013

Dana, D./Zăgreanu, R., Deux dédicaces latines de Porolissum, Tyche. Beiträge zur Alten Geschichte, papyrologie und Epigraphik 28, 27-35.

DUŠANIĆ 1999

Dušanić, S. The Miners' Cults in Illyricum, Pallas 50, 129139.

HORSTER 2001.

Horster, M. Bauinschriften römischer Kaiser. Untersuchungen zur Inschriftenpraxis und Bautätigkeit in den Städten des westlichen Imperium Romanum (Stuttgart: Franz Steiner).

IDR

ILJUG

Inscripțiile Daciei romane (Bucharest-Paris).

Inscriptiones latinae in Jugoslavia repertae (Ljubljana).

KURZMANN 2005

Kurzmann, R., Soldier, Civilian and Military Brick Production, Oxford Journal of Archaelogy, 24(4), 405-414.

LE BOHEC 1992

Le Bohec, Y., Les estampilles de l'armée romaine sur briques et sur tuiles, Epigraphica 54, 43-62.

LÖRINCZ 1991

Lörincz, B., Pannonische Ziegelstempel und die militärischen Territorien. In: Maxfield, V.A./Dobson, B. J. (eds.), Roman Frontier Studies 1989. Proceedings of the XVth International Congress of Roman Frontier Studies (Exeter: University of Exeter Press), 244- 254.

\section{MATEI-POPESCU/ȚENTEA 2016}

Matei-Popescu, F./Țentea O., The Eastern Frontier of Dacia. A Gazetteer of the Forts and Units. In: Bârcă, V. (ed.), Orbis Romanus and Barbaricum. The Barbarians aroind the Province of Dacia and Their relations with the Roman Empire (ClujNapoca: Mega Publishing House), 7-24.

MIHAILESCU-BÎRLIBA 2006

Mihailescu-Bîrliba, L., Les affranchis dans les provinces romaines de l'Illyricum (Wiesbaden: Harrassowitz Verlag).

MIHAILESCU-BÎRLIBA 2016

Mihailescu-Bîrliba, L. Les salines en Dacie romaine: remarques sur le personnel administratif, Studia Antiqua et Archaeologica 22 (1), 51-58.

NEMETI 2005

Nemeti, S., Sincretismul religios în Dacia romană (ClujNapoca: Presa Universitară Clujeană).

\section{NEMETI 2013}

Nemeti, S., La religione dei Daci in età romana. In: Tauffer, M. (ed.), Sguardi interdisciplinary sulla religiosità dei GetoDaci (Freiburg i. Br Berlin/Wien: Rombach Verlag KG), 137155.

\section{NEMETI/NEMETI 2010}

Nemeti, I./Nemeti, S. The barbarians within. Illurian colonists in Roman Dacia, Studia Historica. Historia Antigua 28, 2010, 109-133.

\section{OLTEAN 2007}

Oltean, I. A., Dacia: Landscape, Colonisation, and Romanisation (London-New York: Routledge).

\section{OTA/LASCU 2011}

Ota, R./Lascu, I. Cercetări arheologice în canabae legionis XIII Geminae / Municipium Septimium Apulense - sectorul estic, Acta Musei Porolissensis 33, 201-220.

\section{POPOVICI/VARGA 2010}

Popovici, P./Varga, R., Ad Vatabos. Monografie arheologică a SANIE 1981 localității Războieni-Cetate (Cluj-Napoca: Editura Mega).

Sanie, S., Cultele orientale în Dacia romană. I. Cultele siriene și VARGA 2012 palmiriene (Bucharest: Editura Științifică și Enciclopedică).

Varga, R., Pre-excavation research at the site of Ala I Batavorum (Dacia). In Börner, W., Uhlritz, S., Dollhofer, L. (eds.), International Conference on Cultural Heritage and New Technologies, November 14-16 2011. Proceedings (Vienna), 806-820.

\section{WOLLMANN 1996}

Wollmann, V. Mineritul metalifer, extragerea sării și carierele de piatră în Dacia romană (Cluj-Napoca: Muzeul Național de Istorie a Transilvaniei). 


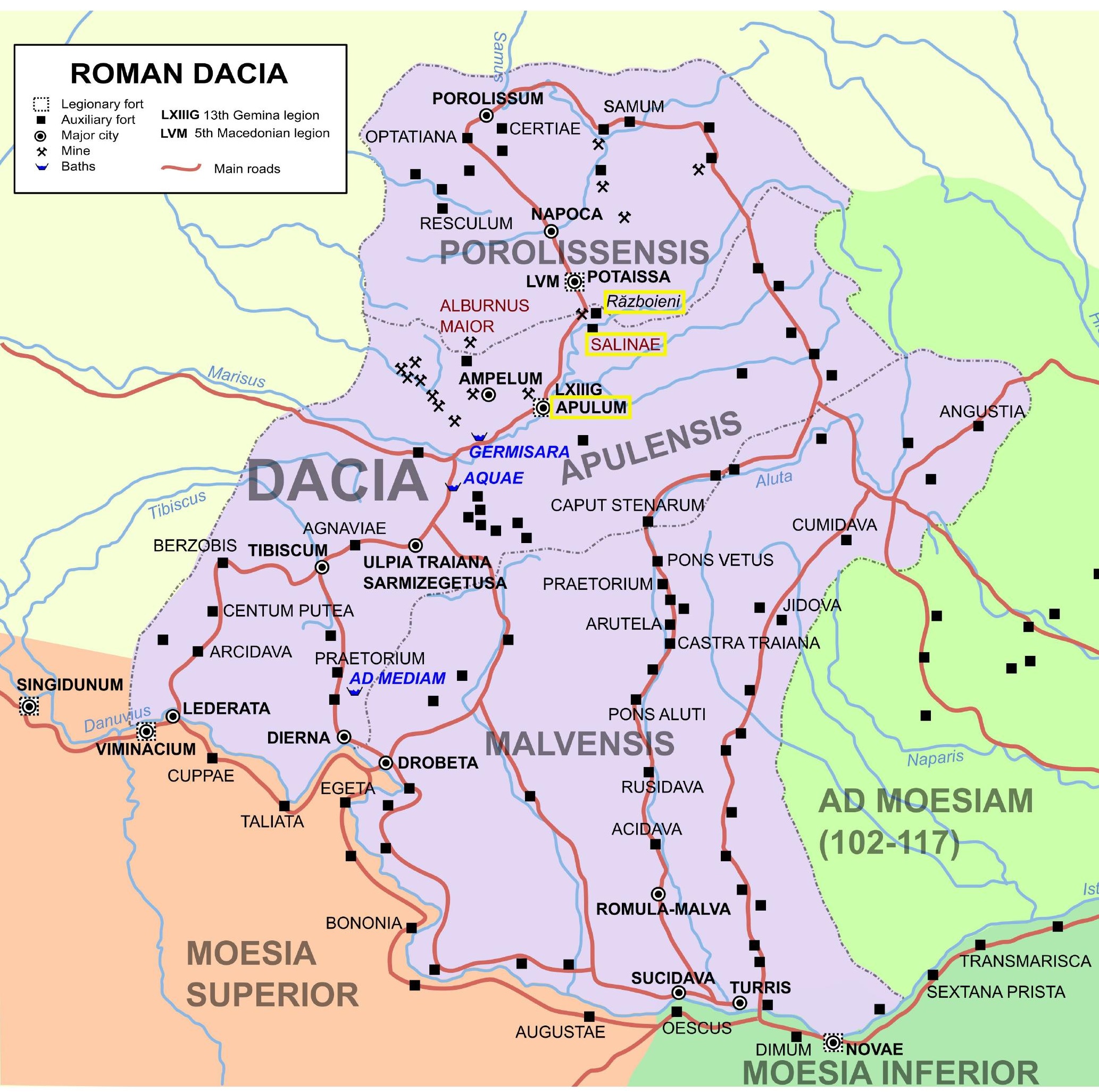

